\title{
Outsourcing and Changes of Business Models of Polish Enterprises - Research Results
}

\author{
Jakub DRZEWIECKI \\ Wroclaw University of Economics, Wroclaw, Poland \\ jakub.drzewiecki@ue.wroc.pl
}

\begin{abstract}
The main goal of the paper is to identify and measure the strength of relations between changes made in different elements of business models of Polish companies using outsourcing. In particular, the presented findings should answer the question regarding the importance of Value Proposition (being, according to most of the business model concepts, its central element), as well as show the influence of using outsourcing on changes made within the business model. The paper presents the results of research among 281 Polish companies, and the main research method was a questionnaire survey. The research presented here confirms the systemic nature of the business model. Statistically important dependencies were observed between the changes made in specific elements of the business model, both quantitative and qualitative. The use of outsourcing by the companies forming the research sample was reflected in modifications of their business models. The research results seem to prove the empirical importance of Alexander Osterwalder's business model framework. Firstly, all the nine elements of Osterwalder's business model framework are interrelated; secondly, the Value Proposition appears to be indeed the central element of a business model. From managerial perspective, the results show the importance of business model approach in strategic management, especially when planning and managing strategic changes within a company.
\end{abstract}

Keywords: Business Model, Outsourcing, Strategic Management, Management Change, System Approach.

\section{Introduction}

Business models are becoming increasingly important, both in theoretical and practical management fields. This fact is evident in the rising number of publications on the subject (growing steadily for at least a decade, and including results of research into the matter of business models), but also in the increasing presence of business models in strategic management practice (thus proving the use of business models as a management tool). The many profits of using business models, which result from their specific traits, prove their usefulness $[2,3,4,8,9,10,15]$. While the concept of a business model is yet to be defined in a single, "true" way that would be accepted by the majority [14], the key traits that make it interesting in both theory and practice of 
strategic management can nevertheless be listed. Of these traits, two are especially important in the light of the research results presented in this paper.

The first is a consequence of the systemic nature of a business model. Regardless of the ideas on its character (e.g. its elements and their number), a business model assumes a correlation between its elements. And, like in any organization, a change in one area of the model requires adjustment of other area(s). This raises questions as to the nature and strength of the interrelations between the various elements of a business model.

The second important trait, one that distinguishes a business model from organization models (like the $7 \mathrm{~S}$ model, for instance), is the fact of taking into account the organization environment. The business model sees beyond the organization itself and to the environment in which it operates, underlining the importance of various elements of that environment (usually partners and clients) in identifying and implementing strategies. This aspect of the business model becomes especially important if a company outsources any of its functions, and therefore has to keep relations with outside entities (outsourcing partners), and to adjust other elements of its business model. Therefore, another important research question is the influence of outsourcing on the shape of the business model of companies which use it.

Both of the aforementioned traits (as well as the research questions) have been taken into consideration in the research carried out by the author. Therefore, the main goal of the paper is to identify and measure the strength of relations between changes made in different elements of business models of Polish companies using outsourcing. In particular, the presented findings should answer the question regarding the importance of Value Proposition (being the central element of business model), as well as show the influence of using outsourcing on changes made within the business model. The starting point of the research presented in this paper is the business model as described by Alexander Osterwalder [11]. The paper presents the results of research among 281 Polish companies, and the main research method was a questionnaire survey.

\section{Methodology of the research and characterization of research sample}

The research tool used during the research described in the paper was a survey questionnaire. Four channels of communication were used in order to initiate contact with the respondents: traditional mail, electronic mail, direct contact and via telephone. The research sample included 281 cases, and the data regarding the model of contact with the respondents (including the size of the investigated enterprises determined, according to criteria stipulated in the Act from 2nd July 2004 on Freedom of Economic Activity, Journal of Laws 2004 No. 173, item 1807) as shown in the table 1: 
Table 1. The model of contact with the respondents divided by the enterprise size.

\begin{tabular}{ccccc}
\hline & \multicolumn{3}{c}{ Size of enterprise } & \\
\cline { 2 - 5 } Model of contact & Small & Medium & Big & Sum (\%) \\
\hline Electronic mail & 3 & 2 & 2 & $\mathbf{7}(\mathbf{2 . 5 \%})$ \\
Traditional model & 7 & 2 & 1 & $\mathbf{1 0}(\mathbf{3 . 6 \%})$ \\
Direct contact & 18 & 4 & 5 & $\mathbf{2 7}(\mathbf{9 . 6 \%})$ \\
Telephone & 75 & 101 & 61 & $\mathbf{2 3 7}(\mathbf{8 4 . 3 \%})$ \\
Sum $(\%)$ & $\mathbf{1 0 3}(\mathbf{3 6 . 6 \%})$ & $\mathbf{1 0 9}(\mathbf{3 8 . 8 \%})$ & $\mathbf{6 9}(\mathbf{2 4 . 6 \%})$ & $\mathbf{2 8 1}(\mathbf{1 0 0 \%})$ \\
\hline
\end{tabular}

The research sample was purposive. Alongside the criterion of using outsourcing two additional criteria were used (arising from the specifics of the project, by which the research was financed):

- the source of capital: the research included Polish enterprises ,

- the size of employment: only enterprises employing at least ten employees [5].

The characterization of the research sample in the cross-section of selected quality features (organizational and legal frame, scope of diversification, and business area) is displayed in table 2:

Table 2. The characterization of the research sample in the cross-section of selected quality features.

\begin{tabular}{ccccc}
\hline \multirow{2}{*}{$\begin{array}{c}\text { Organizational and legal frame } \\
\text { of business activity }\end{array}$} & \multicolumn{3}{c}{ Size of enterprise } & \multirow{2}{*}{ Sum (\%) } \\
\cline { 2 - 4 } & Small & Medium & Big & \\
\hline State owned enterprise & 1 & 2 & 7 & $10(3.6 \%)$ \\
Joint stock company & 3 & 5 & 19 & $27(9.6 \%)$ \\
Civil law partnership & 21 & 50 & 13 & $84(29.9 \%)$ \\
General partnership & 12 & 9 & 4 & $25(8.9 \%)$ \\
Limited partnership & 0 & 0 & 1 & $1(0.3 \%)$ \\
Limited liability company & 22 & 20 & 24 & $66(23.5 \%)$ \\
Business run by a natural person & 44 & 23 & 1 & $68(24.2 \%)$ \\
$\quad$ Sum & $\mathbf{1 0 3}$ & $\mathbf{1 0 9}$ & $\mathbf{6 9}$ & $\mathbf{2 8 1}$ \\
$\quad \begin{array}{c}\text { Area of business } \\
\text { Activity only on domestic market }\end{array}$ & 66 & 72 & 30 & $168(59.8 \%)$ \\
Activity mostly on foreign & 2 & 3 & 5 & $10(3.6 \%)$ \\
markets & & & & $103(36.6 \%)$ \\
Activity mostly on domestic & 35 & 34 & 34 & \\
market & & & & \\
$\begin{array}{c}\text { Degree of diversification } \\
\text { Enterprise operating in one }\end{array}$ & 53 & 52 & 21 & $126(44.8 \%)$
\end{tabular}


sector (branch)

\begin{tabular}{|c|c|c|c|c|}
\hline $\begin{array}{l}\text { Enterprise operating in several } \\
\text { related sectors (branches) }\end{array}$ & 45 & 53 & 31 & $129(45.9 \%)$ \\
\hline $\begin{array}{c}\text { Enterprise operating in several } \\
\text { unrelated sectors (branches) }\end{array}$ & 4 & 3 & 7 & $14(5 \%)$ \\
\hline $\begin{array}{l}\text { Enterprise operating in a dozen } \\
\quad \text { or so sectors (branches) }\end{array}$ & 1 & 1 & 10 & $12(4.3 \%)$ \\
\hline
\end{tabular}

Almost one third of the research sample were comprised of civil law partnerships, around one fourth - limited liability companies and businesses run by a natural person. Roughly every tenth subject being a part of the sample was organized in the form of a joint stock company; in total, share-holding companies equaled to one third of cases. Most of the subjects comprising the research sample (nearly 60\%) operated the business only on a domestic market while more than one third was active mainly on the domestic market. The degree of diversification of investigated subjects should be evaluated as low: more than $90 \%$ of enterprises operated its business either in one branch or at most few related branches [5].

\section{Factors of business model variability}

As it was mentioned in the introduction, the factors of variability of a business model were determined based on the definition and construction of business model created by A. Osterwalder [11]. In this conceptualization, the business model is comprised of nine elements presented and described briefly in table 3:

Table 3. The characterization of the research sample in the cross-section of selected quality features.

\begin{tabular}{|c|c|c|}
\hline $\begin{array}{l}\text { Main areas } \\
\text { of the model }\end{array}$ & $\begin{array}{c}\text { Elements constituting the } \\
\text { business model }\end{array}$ & Description of the elements \\
\hline Product & Value proposition & $\begin{array}{l}\text { Gives general overview on the } \\
\text { benefits offered to customers }\end{array}$ \\
\hline \multirow{3}{*}{ Customer } & $\begin{array}{l}\text { Customer segmentation } \\
\text { (target group) }\end{array}$ & $\begin{array}{l}\text { Describes the segment(s) of } \\
\text { customers to whom a company } \\
\text { wants to offer its values }\end{array}$ \\
\hline & Distribution channels & $\begin{array}{l}\text { Describes the channels of } \\
\text { distributing offers, communication } \\
\text { and contact points with customers }\end{array}$ \\
\hline & $\begin{array}{l}\text { Communication with } \\
\text { customers (relations with } \\
\text { customers) }\end{array}$ & $\begin{array}{l}\text { Explains the way in which a } \\
\text { company builds and maintains } \\
\text { relations with customers }\end{array}$ \\
\hline \multirow{2}{*}{$\begin{array}{l}\text { Infrastruc- } \\
\text { ture } \\
\text { management }\end{array}$} & $\begin{array}{c}\text { Key activities (configuration } \\
\text { of activities) }\end{array}$ & $\begin{array}{l}\text { Describes the system of activity } \\
\text { which a company undertakes in } \\
\text { order to deliver the values }\end{array}$ \\
\hline & Key competences (resources) & Identifies key skills essential to \\
\hline
\end{tabular}


Partners network

Structure of costs

Financial

aspects use a certain business model

Presents the network of cooperation links essential to create and deliver values to the market

Determines the financial consequences of running the business model based on a specific model

Determines the sources of income tanks to which a company earns money

Based on the earlier author's research and Alexander Osterwalder`s business model framework described in detail in: [6, 7], seventeen quantitative and nineteen qualitative factors of business model alterations were identified. These factors are presented in table 4:

Table 4. Factors of quantitative and qualitative alterations of a business model.

\begin{tabular}{|c|c|c|}
\hline $\begin{array}{c}\text { Business model } \\
\text { ingredient } \\
\text { (area) }\end{array}$ & $\begin{array}{l}\text { Quantitative changes } \\
\text { factors [variable code] }\end{array}$ & $\begin{array}{l}\text { Qualitative changes factors } \\
\text { [variable code] }\end{array}$ \\
\hline Client segments & $\begin{array}{l}\text { - Amount of client } \\
\text { segments/groups serviced } \\
{\left[\mathrm{QA}_{1}\right]}\end{array}$ & $\begin{array}{l}\text { - Changes aiming to reach } \\
\text { larger groups of clients within } \\
\text { currently serviced segment(s) } \\
{\left[\mathrm{QL}_{1}\right]} \\
\text { - Changes in the method of } \\
\text { identifying the key client } \\
{\left[\mathrm{QL}_{2}\right]} \\
\text { - Actions aiming to reduce the } \\
\text { least profitable clients }\left[\mathrm{QL}_{3}\right]\end{array}$ \\
\hline $\begin{array}{c}\text { Value } \\
\text { proposition }\end{array}$ & $\begin{array}{l}\text { - Amount of } \\
\text { products/services offered } \\
\text { [QA } 2] \\
\text { - Amount of after-sale } \\
\text { services offered }\left[\mathrm{QA}_{3}\right] \\
\text { - Activity fields (markets, } \\
\text { branches) [QA } 4 \\
\text { - Products/services prices } \\
\left.\text { [QA }{ }_{5}\right]\end{array}$ & $\begin{array}{l}\text { - Perfecting existing } \\
\text { products/services }\left[\mathrm{QL}_{4}\right] \\
\text { - Perfecting the after-sale } \\
\text { services [QL } 5 \text { ] } \\
\text { - Perfecting client problem } \\
\text { solving methods [QL } 6 \text { ] }\end{array}$ \\
\hline Channels & $\begin{array}{l}\text { - Amount of } \\
\text { sales/distribution channels } \\
\text { [QA } 6] \\
\text { - Amount of after-sale } \\
\text { services channels }\left[\mathrm{QA}_{7}\right]\end{array}$ & $\begin{array}{l}\text { - Perfecting the method of } \\
\text { product/service supply } \\
\text { (distribution channels) }\left[\mathrm{QL}_{7}\right] \\
\text { - Perfecting the means and } \\
\text { channels of after-sale services } \\
{\left[\mathrm{QL}_{8}\right]}\end{array}$ \\
\hline
\end{tabular}




\begin{tabular}{|c|c|c|}
\hline Client relations & $\begin{array}{l}\text { - Client communication } \\
\text { channels }\left[\mathrm{QA}_{8}\right]\end{array}$ & $\begin{array}{l}\text { - Perfecting customer service } \\
\text { [QL } 9] \\
\text { - Optimisation - perfecting } \\
\text { marketing tools }\left[\mathrm{QL}_{10}\right] \\
\text { - Changes in building and } \\
\text { maintaining client relations } \\
{\left[\mathrm{QL}_{11}\right]}\end{array}$ \\
\hline Key activities & $\begin{array}{l}\text { - Amount of key activities } \\
\text { performed as part of value } \\
\text { creation process }\left[\mathrm{QA}_{9}\right] \\
\text { - Processes/functions } \\
\text { performed by the } \\
\text { company }\left[\mathrm{QA}_{10}\right]\end{array}$ & $\begin{array}{l}\text { - Implementing new actions } \\
\text { vital for value creations } \\
\text { processes }\left[\mathrm{QL}_{12}\right] \\
\text { - Perfecting the methods of } \\
\text { implementing } \\
\text { processes/functions }\left[\mathrm{QL}_{13}\right]\end{array}$ \\
\hline Key resources & $\begin{array}{l}\text { - Amount of human } \\
\left.\text { resources [QA } \mathrm{Q}_{11}\right] \\
\text { - Amount of physical } \\
\left.\text { resources [QA } \mathrm{Q}_{12}\right] \\
\text { - Amount of financial } \\
\text { resources }\left[\mathrm{QA}_{13}\right]\end{array}$ & $\begin{array}{l}\text { - Obtaining new employees } \\
\text { with new skills }\left[\mathrm{QL}_{14}\right] \\
\text { - Obtaining new employees } \\
\text { with rare skills }\left[\mathrm{QL}_{15}\right] \\
\text { - Obtaining new technology } \\
\left.\text { [QL } \mathrm{Q}_{16}\right]\end{array}$ \\
\hline Key partners & $\begin{array}{l}\text { - Amount of key partners } \\
{\left[\mathrm{QA}_{14}\right]}\end{array}$ & $\begin{array}{l}\text { - Changes in the evaluation } \\
\text { criteria of the key partner } \\
{\left[\mathrm{QL}_{17}\right]} \\
\text { - Changes in the type of } \\
\text { resources obtained from the } \\
\text { key partner }\left[\mathrm{QL}_{18}\right]\end{array}$ \\
\hline Income streams & $\begin{array}{l}\text { - Amount of income } \\
\text { sources }\left[\mathrm{QA}_{15}\right] \\
\text { - Amount of payment } \\
\text { methods (forms) for } \\
\left.\text { products/services [QA }{ }_{16}\right]\end{array}$ & - none \\
\hline Cost structure & $\begin{array}{l}\text { - Amount of cost items } \\
{\left[\mathrm{QA}_{17}\right]}\end{array}$ & $\begin{array}{c}\text { - Actions aiming at cost } \\
\left.\text { optimisation [QL } \mathrm{Q}_{19}\right]\end{array}$ \\
\hline
\end{tabular}

In the case of the variables determining the changes of quantitative factors, the respondents' (CEOs, Board members) task was to specify the degree (scope) of the changes of such factors. An 11-point Likert scale (including the zero score) was adopted, with the variables assuming values from -5 ("considerable decrease in, limitation of the quantity of, reduction of a given component"), to 0 (meaning "no changes of a component"), to +5 ("considerable increase in a component"). In the case of the variables determining the changes of qualitative factors, the respondents' task was to specify the nature of the changes of such factors. A 6-point ordinal Likert scale was adopted, with the variables assuming values from 0 to 5 ( 0 meant "changes with no significant impact on the form of the business model and company's activities", 5 - "fundamental changes that are revolutionary for the company"). 


\section{$4 \quad$ Results of research}

The correlation levels between all identified variables are calculated using $\mathrm{R}$. Spearman's coefficient (Spearmans`s rhos, rank correlation). All the correlations presented in the article were important for the entirety of the research sample, with their importance reaching at least $95 \%(\mathrm{p}<0.05)$. The analysis was carried out both for the variables constituting quantitative and qualitative factors, as well as between those two groups of variables.

Correlation coefficients were positive and medium to high [1] for most quantitative change factors. Correlations between the following variables are especially interesting:

- QA13 and QA15 $(\mathrm{R}=0,72)$

- QA14 and QA8 $(\mathrm{R}=0,66)$

- QA14 and QA3 $(\mathrm{R}=0,60)$

- QA9 and QA13 ( $\mathrm{R}=0,62), \mathrm{QA15}(\mathrm{R}=0,64), \mathrm{QA16}(\mathrm{R}=0,72)$

- QA5 and QA7 $(\mathrm{R}=0,62)$

These results seem to confirm the relevance of business model logic as presented by A. Osterwalder. Interestingly, using outsourcing has had a visible influence on the business model (changes in the key partners area are strongly correlated with other elements of the business model). Correlations were especially strong in the left part of the model (called "infrastructure" by A. Osterwalder), which may mean that the companies forming the sample concentrated on cost effectiveness; the use of outsourcing seems to be an important factor in that. In the case of quantitative changes, the size of a company influences the correlation level between the variables, and said level is higher for big companies than for small firms.

Similarly to the quantitative changes factor, the correlation coefficients for qualitative changes factors were positive and mostly medium to high, with the medium correlation level being higher. The correlations between the following variables are especially interesting:

- $\mathrm{QL}_{17}$ and $\mathrm{QL}_{2}(\mathrm{R}=0,70), \mathrm{QL}_{8}(\mathrm{R}=0,74)$

- $\mathrm{QL}_{18}$ and $\mathrm{QL}_{2}(\mathrm{R}=0,61), \mathrm{QL}_{8}(\mathrm{R}=0,70)$

- $\mathrm{QL}_{11}$ and $\mathrm{QL}_{13}(\mathrm{R}=0,67)$

- $\mathrm{QL}_{8}$ and $\mathrm{QL}_{2}(\mathrm{R}=0,70), \mathrm{QL}_{5}(\mathrm{R}=0,68)$

In the case of qualitative changes factors, there are relations between the left and right side of the business model, and these relations are stronger than in the case of quantitative factors. The most interesting are the changes in the key partners area, and in the client segments $\left(\mathrm{QL}_{17}, \mathrm{QL}_{18}\right.$ and $\left.\mathrm{QL}_{2}\right)$ and channels $\left(\mathrm{QL}_{8}\right)$. This may be due to outsourcing (the importance of cooperation and inter-organizational networks). There is also a relatively high correlation between the $\mathrm{QL}_{8}, \mathrm{QL}_{10}$ and $\mathrm{QL}_{11}$ variables (change factors for channels and client relations). This may be due to the companies being strongly client-oriented. Similarly to the quantitative changes, the size of an enterprise influenced the dependencies between the variables, which were higher for large firms. 
This seems to prove a more conscious approach to strategic management change in larger enterprises.

The analysis of empirical research results attempted to establish the correlation between the quantitative change factors (described through the QA variables) and the quantitative changes in each of the nine business model elements as described by Osterwalder (see Table 3). Thus, the variables within the specific areas of the model were aggregated. Table 5 shows the rank correlation coefficients (Spearman's rhos) for the QA variables (quantitative changes factors), and the aggregates of variables responsible for qualitative changes in business models of the examined companies:

Table 5. Correlations between the scope of quantitative and qualitative changes (divided into specific elements of the business model).

\begin{tabular}{ccccccccc}
\hline & \multicolumn{7}{c}{ Spearman`s rhos (marked are the rhos $\geq \mathbf{0 , 5})$} \\
\cline { 2 - 10 } $\begin{array}{c}\text { Varia- } \\
\text { ble } \\
\text { Code }\end{array}$ & $\begin{array}{c}\text { Custo- } \\
\text { mer } \\
\text { Seg- } \\
\text { ments }\end{array}$ & $\begin{array}{c}\text { Value } \\
\text { Proposi- } \\
\text { tion }\end{array}$ & $\begin{array}{c}\text { Distri- } \\
\text { bution } \\
\text { Channel } \\
\text { s }\end{array}$ & $\begin{array}{c}\text { Client } \\
\text { Rela- } \\
\text { tions }\end{array}$ & $\begin{array}{c}\text { Key } \\
\text { Activi- } \\
\text { ties }\end{array}$ & $\begin{array}{c}\text { Key } \\
\text { Resour } \\
\text {-ces }\end{array}$ & $\begin{array}{c}\text { Key } \\
\text { Part- } \\
\text { ners }\end{array}$ & $\begin{array}{c}\text { Cost } \\
\text { Struc- } \\
\text { ture }\end{array}$ \\
\hline QA $_{1}$ & 0.42 & 0.45 & 0.27 & 0.30 & 0.35 & 0.30 & 0.33 & 0.33 \\
$\mathrm{QA}_{2}$ & 0.38 & 0.48 & 0.37 & 0.37 & 0.37 & 0.46 & 0.44 & 0.40 \\
$\mathrm{QA}_{3}$ & 0.48 & 0.59 & 0.48 & 0.44 & 0.42 & 0.48 & 0.47 & 0.30 \\
$\mathrm{QA}_{4}$ & 0.39 & 0.51 & 0.40 & 0.40 & 0.46 & 0.52 & 0.44 & 0.44 \\
$\mathrm{QA}_{5}$ & 0.47 & 0.45 & 0.47 & 0.48 & 0.40 & 0.51 & 0.50 & 0.36 \\
$\mathrm{QA}_{6}$ & 0.46 & 0.59 & 0.49 & 0.48 & 0.46 & 0.51 & 0.42 & 0.33 \\
$\mathrm{QA}_{7}$ & 0.50 & 0.57 & 0.61 & 0.62 & 0.58 & 0.58 & 0.57 & 0.44 \\
$\mathrm{QA}_{8}$ & 0.41 & 0.56 & 0.45 & 0.50 & 0.47 & 0.38 & 0.38 & 0.41 \\
$\mathrm{QA}_{9}$ & 0.43 & 0.50 & 0.43 & 0.38 & 0.46 & 0.45 & 0.52 & 0.35 \\
$\mathrm{QA}_{10}$ & 0.57 & 0.60 & 0.47 & 0.51 & 0.58 & 0.42 & 0.50 & 0.44 \\
$\mathrm{QA}_{11}$ & 0.42 & 0.45 & 0.34 & 0.32 & 0.31 & 0.43 & 0.40 & 0.36 \\
$\mathrm{QA}_{12}$ & 0.43 & 0.49 & 0.44 & 0.39 & 0.41 & 0.49 & 0.49 & 0.43 \\
$\mathrm{QA}_{13}$ & 0.37 & 0.47 & 0.42 & 0.37 & 0.38 & 0.55 & 0.51 & 0.41 \\
$\mathrm{QA}_{14}$ & 0.52 & 0.59 & 0.43 & 0.42 & 0.47 & 0.48 & 0.49 & 0.45 \\
$\mathrm{QA}_{15}$ & 0.38 & 0.53 & 0.36 & 0.37 & 0.36 & 0.46 & 0.48 & 0.40 \\
$\mathrm{QA}_{16}$ & 0.50 & 0.49 & 0.47 & 0.48 & 0.40 & 0.50 & 0.53 & 0.38 \\
$\mathrm{QA}_{17}$ & 0.26 & 0.32 & 0.28 & 0.24 & 0.32 & 0.34 & 0.35 & 0.23 \\
\hline & & & & & & & &
\end{tabular}

The analysis of the above data leads to the following three main conclusions:

- The qualitative and quantitative changes made within the elements of the business model were correlated; the level of correlation for most of the variables was medium to high. 
- The correlation between $\mathrm{QA}_{\mathrm{x}}$ variables and the variables reflecting changes made in the Value Proposition (VP) was the highest, compared to other eight elements. This was relevant for all the researched companies, regardless of their size. The relations between VP and quantitative changes made within: Distribution Channels $\left(\mathrm{QA}_{6}, \mathrm{QA}_{7}\right)$, Customer Relations $\left(\mathrm{QA}_{8}\right)$, Key Activities $\left(\mathrm{QA}_{9}, \mathrm{QA}_{10}\right)$ and Key Partners $\left(\mathrm{QA}_{14}\right)$ are the strongest. This seems to prove the importance of Value Proposition for the shape of business model of an enterprise.

- Qualitative Changes made both in Key Partners and Key Resources areas of the business model were strongly correlated with its other elements. Again, the form of cooperation with company`s business partners influences the shape of business model due to the fact of using outsourcing by the researched companies. The importance of Key Resources seems to result from the impact of resources to processes of creating value within the company.

\section{Summary}

The research presented here confirms the systemic nature of the business model. Statistically important dependencies were observed between the changes in specific elements of the business model, both quantitative and qualitative. The use of outsourcing by the companies forming the research sample was reflected in modifications of their business models. This is confirmed by the strong dependencies between the infrastructure elements of the business model (according to A. Osterwalder's approach), between the key partners areas, and between the changes in infrastructure and the client segments.

The research results also seem to prove the empirical importance of Alexander Osterwalder`s business model framework. Firstly, all the nine elements of this particular business model framework are interrelated; secondly, the Value Proposition appears to be indeed the central element of a business model. From managerial perspective, the results show the importance of business model approach in strategic management, especially when planning and managing strategic changes within a company. Managers should also take into consideration the impact of outsourcing on their business models, for using it strongly influences the shape of the business model.

The results presented here can form a basis for further exploring of the subject. Examples of future research problems include: evaluating the effectiveness of the changes in business models, mergers and takeovers (e.g. fusing business models) or problems concerning the dependencies between business models and organization life cycles (with special attention paid to startup`s business models). The process of business model creation, especially at its very beginning, seems also to be unexplored. In this context, apart from using quantitative approach, the qualitative research methods should be used (e.g. IDI, case study etc.). Finally, the constant changes happening in the environment of modern companies require constant monitoring of changes happening within different business model areas. This brings up the issue of using certain methods of measuring both the level and direction of business models changes, which would provide objective, rather than subjective, information for the 
managers. Research into aforementioned fields will add to the total sum of knowledge on management, and help to perfect the business model as a tool of strategic management.

Acknowledgements. The research project was financed by the funds granted by National Science Centre based on the decision no. DEC-2013/09/D/HS4/00583.

\section{References}

1. Aczel A.: Statystyka w zarządzaniu. PWN, Warszawa (2000).

2. Banaszyk, P.: Model biznesu jako podstawa zarządzania strategicznego przedsiębiorstwem. Współczesne Metody Zarządzania Strategicznego Przedsiębiorstwem 43, 7-27 (2004).

3. Bossidy, L., Charan, R.: Szósty zmysł w zarządzaniu firmą. Tworzenie wykonalnych planów i modeli biznesowych. Wydawnictwo MT Biznes, Warszawa (2010).

4. Drzewiecki, J.: Model biznesu jako narzędzie zarządzania strategicznego: zastosowanie, dylematy i wyzwania. Przedsiębiorczość i Zarządzanie 14(13), 65-75 (2013).

5. Drzewiecki, J.: Outsourcing w kontekście obszarów funkcjonalnych polskich przedsiębiorstw - wyniki badań. Zarządzanie. Teoria i praktyka 12(2), 11-18 (2015).

6. Drzewiecki, J.: Opportunities, threats and variability of business models of Polish businesses adapting outsourcing - research results. Modern Management Review 23(4), 100-110 (2016).

7. Drzewiecki, J.: Zmienność modelu biznesowego w kontekście innowacyjności organizacji. Management Forum 4(1), 11-16 (2016).

8. Drzewiecki, J., Niemczyk, J.: Modele biznesowe w zarządzaniu strategicznym. Współczesne Zarządzanie 4, 145-152 (2006).

9. Falencikowski, T.M.: Spójność modeli biznesu. Koncepcja i pomiar. CeDeWu Sp. z o.o., Warszawa (2013).

10. Jabłoński, M.: Podejście scenariuszowe w procesie projektowania i modyfikacji modeli biznesu sektorów kreatywnych. Przedsiębiorstwo we współczesnej Gospodarce - Teoria i Praktyka 4, 49-64 (2016).

11. Osterwalder, A., Pigneur, Y.: Tworzenie modeli biznesowych. Podręcznik wizjonera. Helion, Gli wice (2013).

12. Osterwalder, A., Pigneur, Y., Tucci, C.L.: Clarifying business models: Origins, present and future of the concept. Communications of AIS 15, 1-28 (2005).

13. Stanisz, A.: Przystępny kurs statystyki z zastosowaniem STATISTICA PL na przykładach z medycyny. Tom 1. StatSoft, Kraków (2006).

14. Wirtz, B.W., Pistoia, A., Ullrich, S., Göttel, V.: Business Models: Origin, Development and Future Research Perspectives. Long Range Planning 49(1), 36-54 (2015), http://dx.doi.org/10.1016/j.lrp.2015.04.001.

15. Yang, D., Kim, S., Nam, C., \& Min, J.: Developing a decision model for business process outsourcing. Computers \& Operations Research 34(12), 3769-3778 (2007), http://dx.doi.org/10.1016/j.cor.2006.01.012. 